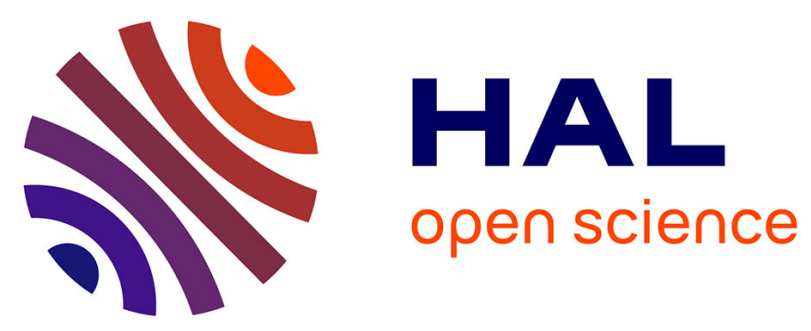

\title{
Organocatalytic enantioselective synthesis of $\beta$-amino sulfonic acid derivatives
}

Emmanuel Deau, Alexandra Le Foll, Clémence Fouache, Emilie Corrot, Laetitia Bailly, Vincent Levacher, Pierric Marchand, Florian Querniard, Laurent Bischoff, Jean-François Brière

\section{To cite this version:}

Emmanuel Deau, Alexandra Le Foll, Clémence Fouache, Emilie Corrot, Laetitia Bailly, et al.. Organocatalytic enantioselective synthesis of $\beta$-amino sulfonic acid derivatives. Chemical Communications, 2021, 57, pp.8348 - 8351. 10.1039/D1CC03477D . hal-03322399

\section{HAL Id: hal-03322399}

https://hal-normandie-univ.archives-ouvertes.fr/hal-03322399

Submitted on 19 Aug 2021

HAL is a multi-disciplinary open access archive for the deposit and dissemination of scientific research documents, whether they are published or not. The documents may come from teaching and research institutions in France or abroad, or from public or private research centers.
L'archive ouverte pluridisciplinaire HAL, est destinée au dépôt et à la diffusion de documents scientifiques de niveau recherche, publiés ou non, émanant des établissements d'enseignement et de recherche français ou étrangers, des laboratoires publics ou privés. 


\section{Organocatalytic enantioselective synthesis of $\beta$-amino sulfonic acid derivatives}

Received 00th January 20xx, Accepted 00th January 20xx DOI: $10.1039 / \times 0 \times x 00000 x$

\author{
Emmanuel Deau, ${ }^{a}$ Alexandra Le Foll, ${ }^{a}$ Clémence Fouache, ${ }^{a}$ Emilie Corrot, ${ }^{a}$ Laetitia Bailly, ${ }^{a},{ }^{+}$Vincent \\ Levacher, ${ }^{a}$ Pierric Marchand, ${ }^{b}$ Florian Querniard, ${ }^{b}$ Laurent Bischoff*a and Jean-François Brière*a
}

An unprecedented enantioselective conjugate addition reaction of sodium bisulfite to various nitrostyrenes occurred upon the influence of a bifunctional amino-thiourea organocatalyst; a strategy which opens a straightforward route to unprotected chiral taurines derivatives thanks to the reduction of the obtained $\beta$ nitroethanesulfonic acids into the corresponding amino derivatives.

Highly acidic chiral sulfonic acid derivatives ( $\mathrm{p} K_{\mathrm{a}} \sim 1$ in DMSO), especially displaying an $\alpha$-stereogenic center to $\mathrm{SO}_{3} \mathrm{H},{ }^{1}$ were successfully exploited in a variety of domains ranging from the elaboration of potent pharmaceutical ingredients ${ }^{2}$ to the development of efficient resolution processes by crystallization. ${ }^{3}$ From a historical point of view, the construction of $\alpha$-chiral sulfonic acids were tackled by multistep asymmetric syntheses ${ }^{4,5}$ and the separation of enantiomers from a racemic mixture. $^{3}$ In a perspective of modern sustainable methodologies, however, the enantioselective catalytic introduction of the $\mathrm{SO}_{3} \mathrm{H}$ motif has only emerged recently. ${ }^{6} \mathrm{By}$ re-investigating the conjugate addition of bisulfite to electropoor alkenes, ${ }^{7}$ Adamo pioneered this sulfa-Michael onto chalcone derivatives in an enantioselective fashion by means of bifunctional thioureas-Cinchona alkaloid bases (Scheme $1 \mathrm{~A}) ; 8$ and extended this useful methodology to the synthesis of naturally occurring gingesulfonic acids. ${ }^{8 b}$ This straightforward catalytic strategy was recently extended to $\beta$-trifluoromethyl$\alpha, \beta$-unsaturated ketones by $\mathrm{Xu}$ and Yuan. ${ }^{9}$ Alternatively, Zhao reported on the $\mathrm{Pd}$ and Ir-catalyzed asymmetric allylic sulfonation making use of sodium sulfite (Scheme 1B). ${ }^{10}$ In spite of these promising early achievements in catalysis, the reaction scope, together with the structures of starting materials, and $\alpha$ -

\footnotetext{
a. Normandie Univ, UNIROUEN, INSA Rouen, CNRS, COBRA, 76000 Rouen, France. E-mail: jean-francois.briere@insa-rouen.fr, laurent.bischoff@univ-rouen.fr Web : www.lab-cobra.fr/equipes/heterocycles/

b. Holodiag, Voie de I'Innovation, Pharmaparc 2, 27100 Val de Reuil

+ Analytical department of COBRA.

Electronic Supplementary Information (ESI) available: [details of any supplementary information available should be included here]. See DOI: 10.1039/x0xx00000x
}

chiral sulfonic acid products obtained thereof, remain rather limited.

$$
\text { Organocatalytic asymmetric addition of the } \mathrm{SO}_{3} \mathrm{H}_{\text {motif }}
$$



Scheme 1. Context of the investigation.

The naturally occurring taurine $(\mathrm{R}=\mathrm{H}$, Scheme $1 \mathrm{C})$ and derivatives are fascinating $\beta$-aminoethanesulfonic acids, which have been successfully incorporated into various molecules such as bioactive and biosensor products with improved aqueous solubility in physiological medium, as well as dyes, polymers, etc. ${ }^{11}$ Additionally, peptidosulfonamides provided novel peptides displaying specific electronic and conformational properties leading to unusual biological properties in peptidomimetics. ${ }^{12}$ Notwithstanding the value of these chiral compounds, ${ }^{13}$ few catalytic asymmetric methodologies tackled the construction of precursors of taurines. Upon Brønsted base catalysis, the $(2+2)$ cycloaddition between sulfenes and aldehydes gave rise to the formation of $\beta$-sultams, ${ }^{14}$ while the desymmetrization of meso-aziridines provided the corresponding cyclic $\beta$-aminothioethers. ${ }^{15}$ Then, thanks to the transformation of the sulfur functionality to afford the corresponding $\mathrm{SO}_{3} \mathrm{H}$ products (via oxidation or hydrolysis events), the authors succeeded in the syntheses of taurine derivatives in certain cases. ${ }^{14,15}$ On the other hand, the asymmetric conjugate addition of thiol or thioacetic acid to 
nitrostyrenes has met some success in recent years. ${ }^{16,17}$ Nevertheless, the subsequent oxidation/reduction sequences, required for the formation of $\beta$-aminoethanesulfonic acids, were achieved only from a limited number of aliphatic or disubstituted precursors. ${ }^{16 d, 16 e}$ In this field of research, the direct asymmetric catalytic addition of $\mathrm{NaHSO}_{3}$ to nitrostyrenes is unprecedented, although this sequence would afford a step and atom economy entry to chiral taurine derivatives (Scheme 1C), after a simple reduction procedure of $\beta$ nitroethanesulfonic acid intermediates. ${ }^{7}$ However, this valuable asymmetric strategy should address several challenges such as (1) the design of a suited organocatalyst capable to orchestrate a catalytic process under significantly acidic conditions, (2) to deal with the competitive complexation between the sulfite and nitro functionalities of both the nucleophilic and electrophilic species, and (3) to manage the purification and analysis of the highly polar obtained products (without difficult derivatization events as commonly used procedures thus far in these series). We are pleased to report hereby on the unprecedented enantioselective addition of $\mathrm{NaHSO}_{3}$ to nitrostyrenes under organocatalytic conditions affording an entry to taurine derivatives after a simple hydrogenation of the nitro-sulfonic acid intermediates.
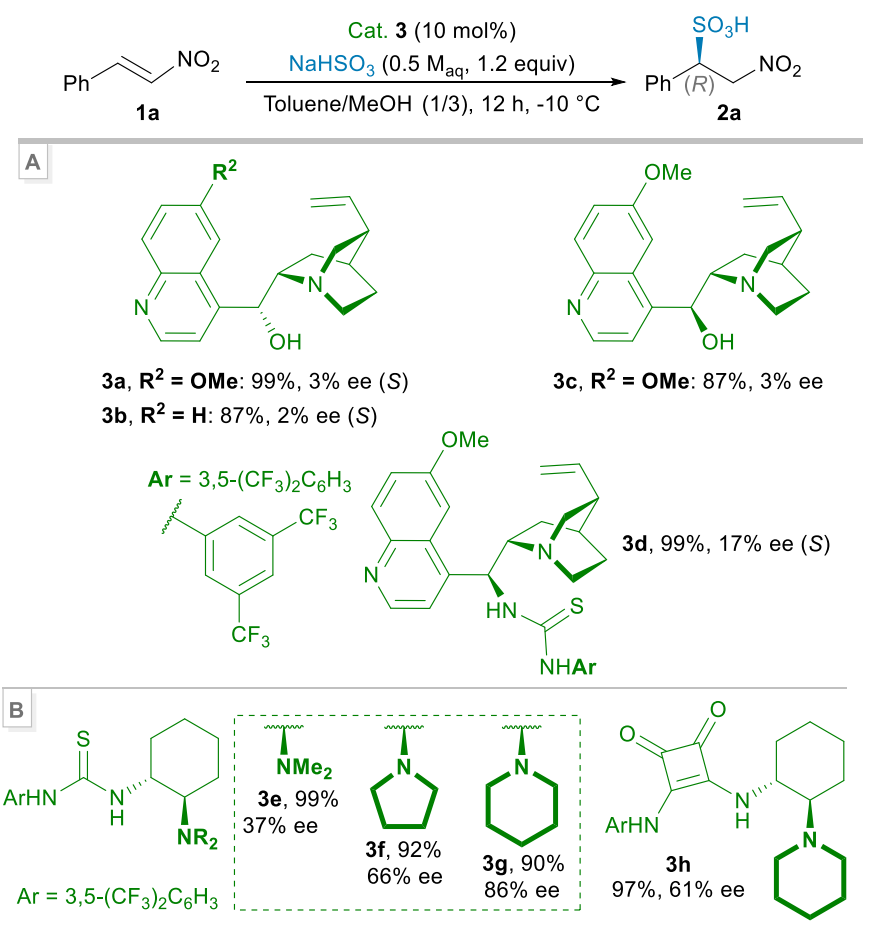

C Variations of conditions with catalyst $3 g(10 \mathrm{~mol} \%)$

- Tol., $170 \mathrm{~h},-10{ }^{\circ} \mathrm{C}$ : $55 \%, 56 \%$ ee

- Variation of catalyst $3 \mathrm{~g}$ loading - $\mathrm{CH}_{2} \mathrm{Cl}_{2} / \mathrm{MeOH}(1 / 3), 12 \mathrm{~h},-10{ }^{\circ} \mathrm{C}: 92 \%, 61 \%$ ee $\quad(20 \mathrm{~mol} \%), 8 \mathrm{~h}: 99 \%, 95 \%$ ee - THF/MeOH (1/3), $12 \mathrm{~h},-10^{\circ} \mathrm{C}: 83 \%, 45 \%$ ee $\quad \bullet(5 \mathrm{~mol} \%), 15 \mathrm{~h}: 92 \%, 80 \%$ ee - Tol. $/ \mathrm{MeOH}(1 / 3), 36 \mathrm{~h},-40{ }^{\circ} \mathrm{C}: 99 \%, 95 \%$ ee $\bullet$ • (15 mol\%), $15 \mathrm{h:} \mathbf{9 9 \%}$, 95\% ee Scheme 2. Reaction optimization. Isolated yields after purification on Dowex 50WX8. Ees of product $\mathbf{2 a}$ were determined by chiral HPLC. The absolute configuration of $\mathbf{2} \mathbf{a}$ was determined by comparison with known compounds by means of $[\alpha]^{\mathrm{D}}$ and chemical transformations (see SI)

The identification of a suited organocatalyst (10 mol\%) commenced by carrying out the sulfa-Michael reaction in
toluene/MeOH at $-10{ }^{\circ} \mathrm{C}$ (Scheme 2A). ${ }^{18}$ The cinchona-derived Brønsted bases 3a-3d turned out to be inefficient in our hand, giving the corresponding nitro sulfonic acid product $2 a$ in $2-17 \%$ enantiomeric excess (ee) after purification on a ion exchange sulfonic acid-based resin and a direct HPLC analysis (Scheme 2A). ${ }^{19,20}$ Nonetheless, the bifunctional Takemoto catalyst $\mathbf{3 e}$, with a cyclohexane diamine backbone, furnished promising $37 \%$ ee in $99 \%$ yield (Scheme $2 \mathrm{~B}$ ). ${ }^{21}$ The modification of the tertiary amine $\mathrm{NR}_{2}$ allowed to improve the ee from $66 \%$ with a pyrrolidinyl moiety (3f, 92\%) to $86 \%$ ee with the piperidylderived catalyst $\mathbf{3 g}$ with an excellent $90 \%$ yield. Obviously, the thiourea part of catalyst $\mathbf{3 g}$ was a more adapted hydrogenbonding donor function than the analogous squaramide on $\mathbf{3 h}$ ( $86 \%$ versus $61 \%$ ee), ${ }^{22}$ showing the subtle topology requirement of the employed catalyst for this sulfa-Michael reaction of bisulfite. With the catalyst $\mathbf{3 g}$ in hands (Scheme $2 \mathrm{C}$ ), the variation of conditions revealed that toluene/ $\mathrm{MeOH}$ (Tol/MeOH: $1 / 3$ ) was the most suited mixture of solvent, both for ee and solubility issues, and a decrease in temperature from $-10{ }^{\circ} \mathrm{C}$ to $-40{ }^{\circ} \mathrm{C}$ secured $95 \%$ ee with $99 \%$ yield albeit in a longer 36 hours of reaction (instead of $12 \mathrm{~h}$ ). ${ }^{18}$ Eventually, a compromise was found with a catalyst $\mathbf{3 g}$ loading of $15 \mathrm{~mol} \%$ which furnished the nitro sulfonic acid product $2 \mathrm{a}$ in $95 \%$ ee and $99 \%$ yield in a reasonable time of 15 hours.

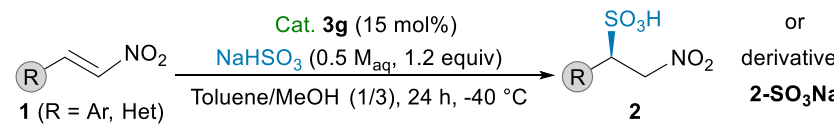

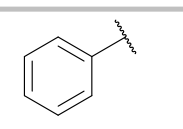

2a, $99 \%, 95 \%$ ee<smiles>CCc1ccc(Cl)cc1Cl</smiles>
$2 e, 96 \%, 86 \%$ ee<smiles></smiles>

i, $94 \%, 81 \%$ ee

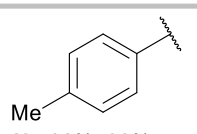

2b, $82 \%, 93 \%$ ee

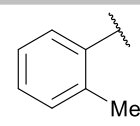

2c, $81 \%, 96 \%$ e



2d, $99 \%, 95 \%$ ee<smiles>CC(C)c1ccc(Br)cc1</smiles>

2f, $99 \%, 93 \%$ ee

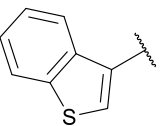

2j, $99 \%, 76 \%$ ee

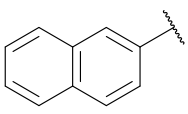

2g, $99 \%, 92 \%$ ee<smiles>CC(C)c1cccs1</smiles>

2k, $98 \%, 85 \%$ ee

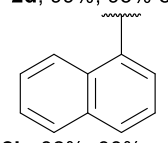

2h, $82 \%, 88 \%$ ee

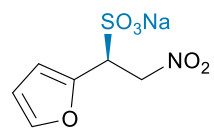

$21-\mathrm{SO}_{3} \mathrm{Na}$

$91 \%, 87 \%$ ee $^{a}$ $(57 \%, 94 \% \text { ee })^{b}$

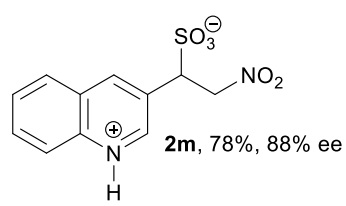<smiles></smiles>

Scheme 3. Scope and limitation in nitro sulfonic acid derivatives. Reaction conditions: nitrostyrene $(0.25-0.5 \mathrm{mmol})$ in toluene/ $\mathrm{MeOH}(1 / 3,0.1 \mathrm{M})$ - Isolated yields after purification on Dowex $50 \mathrm{WX} 8$ and ee determined by HPLC. ${ }^{a}$ Isolated after partitioning between water and $\mathrm{CH}_{2} \mathrm{Cl}_{2}$ layers and evaporation of the aqueous phase. ${ }^{b}$ Precipitation from a $\mathrm{MeOH} /$ acetone/ $/ \mathrm{Et}_{2} \mathrm{O}$ solution.

We subsequently probed the scope and limitation of these novel enantioselective reaction conditions ( 24 hours, $-40{ }^{\circ} \mathrm{C}$ ) toward the synthesis of nitro sulfonic acid products $\mathbf{2}$ (Scheme 3). Pleasingly, the sulfa-Michael process took place efficiently (82-99\% yields) on an array of aryl-substituted nitroalkenes 1a$\mathbf{1 h}$ to afford the corresponding products $\mathbf{2 a - h}$ with ees of 86 $96 \%$ regardless the ortho-substitution (2c, $81 \%, 96 \%$ ee) or the 
para-substitution by a methyl group (2b, $82 \%, 93 \%$ ee), an electron-rich OMe (2d, 99\%, 95\% ee) and even with electronpoor groups (2e-2f, 96\%-99\% and $86-93 \%$ ee respectively). The sterically more hindered naphtyl derivatives $\mathbf{2 g - 2 h}$ (82-99\%) were also successfully synthesized in $88-92 \%$ ee. The nitroalkenes flanked by a heterocycle moiety were transformed into the corresponding sulfonic derivatives $\mathbf{2} \mathbf{i}-\mathbf{2} \mathbf{n}$ but with different outcomes. For instance, $N$-protected indole $\mathbf{2 i}$ (94\%, $81 \%$ ee), benzothiophene $\mathbf{2} \mathbf{j}$ (99\%, 76\% ee) and thiophene $\mathbf{2 k}$ (98\%, 85\% ee) derivatives were obtained with a slight decrease in ee (76-85\%), but the furan product 21 readily decomposed during purification on the acid resin Dowex 50WX8. However, by partitioning the reaction mixture between aqueous and organic layers, the furan-product $\mathbf{2 l}$ was isolated as a sodium sulfonate salt with $91 \%$ yield and $87 \%$ ee. The enantiomeric excess of $\mathbf{2 l}$ was improved to $94 \%$ ee after reprecipitation from a ternary $\mathrm{MeOH} /$ acetone/ $\mathrm{Et}_{2} \mathrm{O}$ solution with an overall $57 \%$ yield. The quinoline $\mathbf{2} \mathbf{m}$ and pyrimidine $\mathbf{2 n}$ adducts were synthesized with $88 \%$ ee ( $78 \%$ yield) and $84 \%$ ee ( $98 \%$ yield) respectively albeit these products were isolated as zwitterionic species, subsequent to the elution through the acid resin.

$$
\text { cat. } \mathbf{3 g}
$$
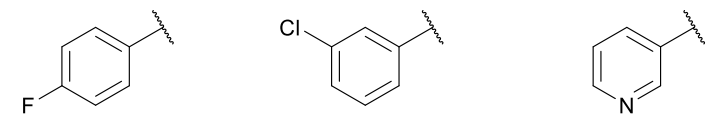
$(0.5-1.5 \mathrm{mmol})$ in toluene/MeOH $(1 / 3,0.1 \mathrm{M})$. Isolated yields after purification on Dowex $50 \mathrm{WX} 8$ and ee measured by chiral HPLC. ${ }^{a}$ Conditions A for reduction: $\mathrm{H}_{2}$ (24 bar), Pd/C $(10 \mathrm{~mol} \%, 20 \% \mathrm{w} / \mathrm{w}), \mathrm{MeOH}, 60^{\circ} \mathrm{C}, 24 \mathrm{~h}$. ${ }^{b}$ Precipitation in $\mathrm{MeOH}$ allowing the isolation of the product in a solid form. 'Conditions B for reduction: $\mathrm{H}_{2}$ (35 bar), $5 \% \mathrm{PtO}_{2}$ ( $5 \mathrm{~mol} \%$ ), $\mathrm{MeOH}, 70{ }^{\circ} \mathrm{C}, 72 \mathrm{~h} .{ }^{d}$ Isolated after column on resin as a zwitterionic species.

At that stage, we faced two issues such as (1) the analysis of several nitro sulfonic acid products 2 proved to be challenging as long as no separation by chiral HPLC was obtained (compounds 2o-2r in Scheme 4), and (2) the reduction of the $\mathrm{NO}_{2}$ into $\mathrm{NH}_{2}$ functional group had to be validated on enantiopure nitro-precursors $\mathbf{2}$ in order to open a route to nonracemic taurine derivatives. Pleasingly, the model nitro sulfonic acid $2 \mathrm{a}$ with a phenyl pendant was reduced $\left(\mathrm{H}_{2}, 24\right.$ bars $)$ in the presence of palladium on charcoal into the corresponding amino sulfonic acid $\mathbf{4 a}$ in $98 \%$ yield and a preservation of the ee to $96 \%$ ee (Scheme 4). In that vein, the enantioselective sulfaMichael and reduction sequence was applied to furnish the products flanked by a para-phenol $(\mathbf{4 b}, \mathbf{9 6 \%}, 93 \%$ ee) or parafluorophenyl moiety (4c, 99\%, 90\% ee) with successful measurement of ee by chiral HPLC. In similar sequence, but carrying out the reduction in the presence of $\mathrm{PtO}_{2}$ instead of $\mathrm{Pd} / \mathrm{C}$, the construction of the meta-chlorophenyl derivative $\mathbf{4 d}$ was allowed in $74 \%$ and $75 \%$ ee without any extensive cleavage of $\mathrm{C}-\mathrm{Cl}$ bond. Additionally, the amino sulfonic acid $4 \mathbf{e}$, having a
2 -pyridyl moiety, was obtained in $97 \%$ yield and good $86 \%$ ee. Interestingly, the compound $\mathbf{4 a} \mathbf{a} \mathbf{4 b}$ and $\mathbf{4 e}$ could be obtained in a solid form after trituration in methanol solution with a slight decrease in yields but rather similar ee.

Based on recent mechanistic investigations, ${ }^{23}$ we propose the Pápai's model to rationalize the asymmetric induction obtained with Takemoto type catalyst $\mathbf{3 g}$ along the catalytic cycle depicted in Scheme 5. ${ }^{23 b}$ After the deprotonation event with the Brønsted base pendant of $\mathbf{3 g}$, giving the ion pair $\mathbf{5}$, the sulfite anion is complexed by the thiourea moiety of the bifunctional catalyst. ${ }^{24}$ Then, the tertiary ammonium part of the protonated catalyst $\mathbf{3 g}$ assists (through hydrogen-bonding in the ternary complex 6 ) the positioning of the Re-face of the nitroalkene electrophile 1 towards the incoming sulfite nucleophile. Finally, the protonation of the transient $(R)$ nitronate $\mathbf{7}$ would occur either by the tertiary ammonium salt in order to afford product $\mathbf{2}-\mathbf{S O}_{3} \mathrm{Na}$ while regenerate the catalyst $\mathbf{3 g}$, or by a molecule of bisulfite en route to another catalytic cycle though ion pair 5 .

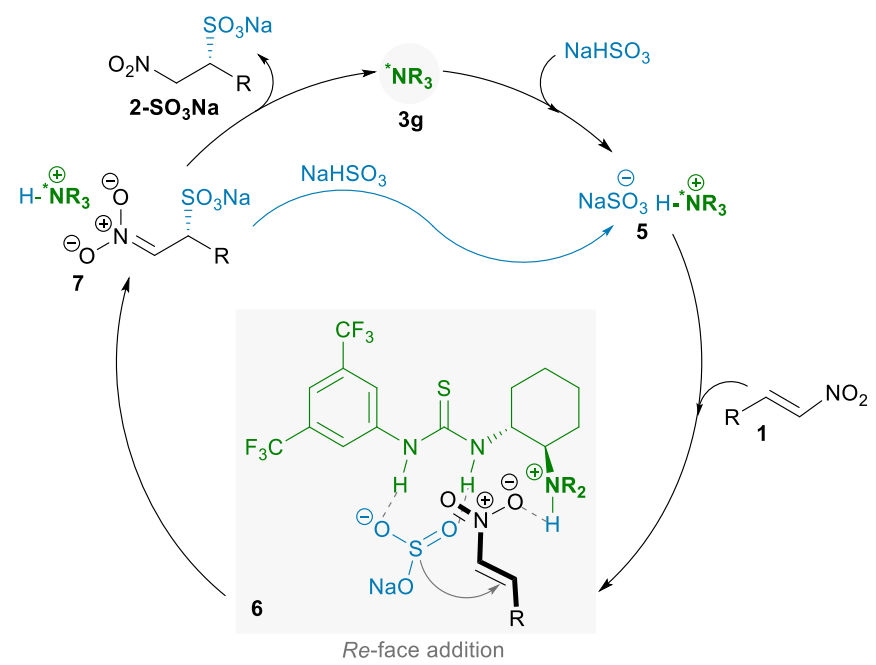

Scheme 5. Proposed model of induction and catalytic cycle.

In conclusion, a straightforward two steps synthesis of valuable, enantioenriched and unprotected taurines -namely $\beta$ aminoethanesulfonic acid derivatives- was developed based on an efficient and unprecedented enantioselective organocatalytic sulfa-Michael of bisulfite to nitrostyrenes, followed by the direct hydrogenation of the nitro functional group. The exploitation of the newly accessible derivatives is currently under investigation in synthesis and catalysis.

This work has been partially supported by INSA Rouen Normandy, University of Rouen Normandy, the Centre National de la Recherche Scientifique (CNRS), EFRD, and Labex SynOrg (ANR-11-LABX-0029), and by Region Normandie (CRUNCh network). This work is part of CrisOrg - LabCom V6 (ANR-14LAB6-0002), Laboratoires communs organismes de recherche publics - PME/ETI - 2014. The authors would like to thank Véronique Chassagne and Emilie Petit for their helps in the synthesis and analysis of sulfonic acid derivatives.

\section{Conflicts of interest}


There are no conflict to declare.

\section{Notes and references}

1. S. Patai, Z. Rappoport and Editors, The Chemistry of Sulfonic Acids, Esters, and Their Derivatives (The Chemistry of Functional Groups), Wiley, 1991.

2. For selected examples, see: (a) S. Morimoto, H. Nomura, T. Ishiguro, T. Fugono and K. Maeda, J. Med. Chem., 1972, 15, 1105 1108; (b) K. Tsuchiya and M. Kondo, Antimicrobial Agents and Chemotherapy, 1978, 13, 536-539; (c) Y. Hori, T. Miura, Y. Hirai, M. Fukumura, Y. Nemoto, K. Toriizuka and Y. Ida, Phytochemistry, 2003, 62, 613-617.

3. For a review on resolution, see:R. M. Kellogg, J. W. Nieuwenhuijzen, K. Pouwer, T. R. Vries, Q. B. Broxterman, R. F. P. Grimbergen, B. Kaptein, R. M. L. Crois, E. de Wever, K. Zwaagstra and A. C. van der Laan, Synthesis, 2003, DOI: 10.1055/s-2003-40508, 1626-1638.

4. For representative diastereoselective approaches, see: (a) R. M. Lawrence, S. A. Biller, J. K. Dickson, J. V. H. Logan, D. R. Magnin, R. B. Sulsky, J. D. DiMarco, J. Z. Gougoutas, B. D. Beyer, S. C. Taylor, S.-J. Lan, C. P. Ciosek, T. W. Harrity, K. G. Jolibois, L. K. Kunselman and D. A. Slusarchyk, J. Am. Chem. Soc., 1996, 118, 11668-11669; (b) D. Enders, N. Vignola, O. M. Berner and J. W. Bats, Angew. Chem. Int Ed., 2002, 41, 109-111; (c) D. Enders, O. M. Berner, N. Vignola and W. Harnying, Synthesis, 2002, 1945-1952; (d) D. Enders, S. Wallert and J. Runsink, Synthesis, 2003, 1856-1868; (e) D. Enders, N. Vignola, O. M. Berner and W. Harnying, Tetrahedron, 2005, 61, 3231-3243.

5. E. J. Corey and K. A. Cimprich, Tetrahedron Lett., 1992, 33, 40994102.

6. For a recent alternative strategy making use of an asymmetric catalytic hydrogenation of $\alpha$-arylethylsulfonic acids, see: X. Yin, C. Chen, X.-Q. Dong and X. Zhang, Org. Lett., 2017, 19, 2678-2681.

7. For early but racemic sulfa-Michael of bisulfite to nitrostyrene, see: (a) R. L. Heath and H. A. Piggott, J. Chem. Soc., 1947, DOI: 10.1039/JR9470001481, 1481-1485; (b) F. Fini, M. Nagabelli and M. F. A. Adamo, Adv. Synth. Catal., 2010, 352, 3163-3168.

8. (a) M. Moccia, F. Fini, M. Scagnetti and M. F. A. Adamo, Angew. Chem. Int. Ed., 2011, 50, 6893-6895; (b) G. Bencivenni, M. Moccia, A Ravelli, M. W. Gillick-Healy, B. G. Kelly and M. F. A. Adamo, Org. Biomol. Chem., 2020, 18, 1091-1094.

9. W.-F. Hu, J.-Q. Zhao, Y.-Z. Chen, X.-M. Zhang, X.-Y. Xu and W.-C. Yuan, J. Org. Chem., 2018, 83, 5771-5777.

10. (a) W. Liu, X.-m. Zhao, H.-b. Zhang, L. Zhang and M.-z. Zhao, Chem. Eur. J., 2014, 20, 16873-16876; (b) W. Liu, X.-m. Zhao, H.-b. Zhang and L. Zhang, Chem. Commun., 2015, 51, 655-657.

11. For a recent and insightful review, see: O. O. Grygorenko, A. V. Biitseva and S. Zhersh, Tetrahedron, 2018, 74, 1355-1421.

12. R. M. J. Liskamp and J. A. W. Kruijtzer, Molecular Diversity, 2004, 8, 79-87.

13. (a) K. Higashiura and K. lenaga, J. Org. Chem., 1992, 57, 764-766; (b) D. Braghiroli and M. D. Bella, Tetrahedron Lett., 1996, 37, 73197322; (c) D. Braghiroli, R. Avallone and M. Di Bella, Tetrahedron: Asymmetry, 1997, 8, 2209-2213; (d) J. Xu, Tetrahedron: Asymmetry, 2002, 13, 1129-1134; (e) For selected syntheses of taurine derivatives from the chiral-pool, see:J. Xu, S. Xu and Q. Zhang, Heteroatom Chem., 2005, 16, 466-471; (f) N. Chen, W. Jia and J. Xu, Eur. J. Org. Chem., 2009, DOI: 10.1002/ejoc.200900759, 5841-5846. 14. (a) F. M. Koch and R. Peters, Angew. Chem. Int. Ed., 2007, 46, 2685-2689; (b) F. M. Koch and R. Peters, Synlett, 2008, DOI: 10.1055/s-2008-1078417, 1505-1509; (c) F. M. Koch and R. Peters, Chem. Eur. J., 2011, 17, 3679-3692.

15. Y. Zhang, C. W. Kee, R. Lee, X. Fu, J. Y.-T. Soh, E. M. F. Loh, K.-W. Huang and C.-H. Tan, Chem. Commun., 2011, 47, 3897-3899.

16. (a) For selected examples, see:K. L. Kimmel, M. T. Robak and J. A. Ellman, J. Am. Chem. Soc., 2009, 131, 8754-8755; (b) H.-H. Lu, F.-G. Zhang, X.-G. Meng, S.-W. Duan and W.-J. Xiao, Org. Lett., 2009, 11, 3946-3949; (c) C. Palacio and S. J. Connon, Chem. Commun., 2012, 48, 2849-2851; (d) D. Uraguchi, N. Kinoshita, D. Nakashima and T. Ooi, Chem. Sci., 2012, 3, 3161-3164; (e) W. Yang and D.-M. Du, Org. Biomol. Chem., 2012, 10, 6876-6884; (f) J. P. Phelan, E. J. Patel and J. A. Ellman, Angew. Chem. Int. Ed., 2014, 53, 11329-11332; (g) R. Wang and J. Xu, Helv. Chim. Acta, 2014, 97, 1700-1707.

17. (a) For reviews on catalytic enantioselective formation of C-S bonds, see:P. Chauhan, S. Mahajan and D. Enders, Chem. Rev., 2014, 114, 8807-8864; (b) J.-S. Yu, H.-M. Huang, P.-G. Ding, X.-S. Hu, F. Zhou and J. Zhou, ACS Catal., 2016, 6, 5319-5344.

18. See Supporting Information (SI) for further information.

19. The determination of the enantiomeric excess by HPLC or GC of chiral sulfonic acids is usually carried out after a required methylation reaction (see references 8-10 for instance). These methylation procedures were not satisfying in our hand on the nitro-derived sulfonic acid products and adapted while challenging chiral reversedphase HPLC conditions were developed for the direct analysis of the obtained products.

20. Interestingly, in similar conditions Adamo demonstrated that catalyst $3 \mathrm{c}$ allowed the addition of $\mathrm{NaHSO}_{3}$ to chalcone with $96 \%$ ee (reference 8).

21. (a) Y. Takemoto, Chem. Pharm. Bull., 2010, 58, 593-601; (b) P. Wang, H.-F. Li, J.-Z. Zhao, Z.-H. Du and C.-S. Da, Org. Lett., 2017, 19, 2634-2637.

22. For reviews, see: (a) J. Alemán, A. Parra, H. Jiang and K. A. Jørgensen, Chem. Eur. J., 2011, 17, 6890-6899; (b) S. Karahan and C. Tanyeli, Tetrahedron Lett., 2018, 59, 3725-3737.

23. (a) T. Okino, Y. Hoashi, T. Furukawa, X. Xu and Y. Takemoto, J. Am. Chem. Soc., 2005, 127, 119-125; (b) A. Hamza, G. Schubert, T. Soós and I. Pápai, J. Am. Chem. Soc., 2006, 128, 13151-13160; (c) J.-L. Zhu, Y. Zhang, C. Liu, A.-M. Zheng and W. Wang, J. Org. Chem., 2012, 77, 9813-9825; (d) M. N. Grayson and K. N. Houk, J. Am. Chem. Soc. 2016, 138, 9041-9044.

24. For an insightful discussion on the reactive monomeric versus the less-reactive dimeric form of bisulfite, and how both the dilution and an external base can influence these equilibriums in favor of the monomeric species, see reference $7 \mathrm{~b}$. 